\title{
TO THE QUESTION OF IMPROVING ENERGY-SAVING AND ENVIRONMENTAL CHARACTERISTICS OF URBAN BUILDINGS
}

\author{
Vladimir Sergeevich Yezhov, Natalia Evgenievna Semicheva*, Ekaterina Gennadievna Pakhomova, \\ Natalia Vladimirovna Bredikhina, Solomon Emmanuel
}

Southwest State University, Kursk, Russian Federation

\begin{abstract}
A new structural material for the production of ventilated facades (ventilated fences) - granulated blast furnace slag, which has high structural, thermal and adsorption properties, allowing to significantly increase the energy-saving and environmental characteristics of ventilated fences and, accordingly, facades of buildings and structures. Developed by the innovative design of ventilated facade (ventilated fencing) based on blast furnace slag, allowing the clear air of the street from a significant part of nitrogen oxides, sulphur oxides, oxides of carbon, soot particles and dust, to reduce the amount of heat delivered to the building in summer and heat loss in winter, which greatly improves the environmental and economic performance of buildings.
\end{abstract}

Key words: Construction material, hinged ventilated facades, building, granulated blast furnace slag, energy saving, ecology, street air, innovative design, cleaning, nitrogen oxides, sulfur oxides, carbon oxides, heat gain, heat loss, economic efficiency of buildings and structures

\section{INTRODUCTION}

Presently, in many developed and developing countries, the construction sector accounts for about 40 per cent of global energy consumption, making improving the energy efficiency of buildings a key challenge for sustainable urban development. In the Russian Federation, for example, the Federal Law No. 261 "On Energy Saving and Energy Efficiency Improvement" of 23 November 2009 aims to create a legal, economic and institutional framework to promote energy saving and energy efficiency in buildings and structures. Therefore, the issues of energy saving are relevant in all sections of the urban economy, including the creation and reconstruction of buildings, which should have high environmental and energy saving characteristics [1, 2, 13].

Facades of buildings are one of the most technologically complex, multifaceted and universal components of the building. In general, from the point of view of architectural design, the facade is one of the most important components of a building demonstrating its aesthetic value and architectural features. From an engineering point of view, the building envelope, including the façade, plays an important role in maintaining the thermal conditions in the room and the strength characteristics of the buildings. Briefly, facades are responsible for the appearance of buildings and the way they function [4]. Indeed, an effectively designed building facade can make buildings function more successfully for its inhabitants and the environment. Similarly, building facades can have an impact on user's satisfaction with their living or working environment in a building. Building facade design is usually a complex problem and requires an interdisciplinary approach, ideally requiring a team of architects, engineers and environmental scientists to work together to achieve optimal design. Building facade design involves consideration of several factors, including the external environment and microclimatic conditions, the environmental characteristics of the room and the spatial characteristics and needs of the occupants [5].

An important component of modern facades are ventilated facade systems (ventilated building envelopes), which have proven their worth in the practice of finishing and cladding of building facades. Today, ventilated facade systems are actively been used in the construction of almost all types of buildings and structures. One of the advantages of ventilated building envelopes is their use in regions with large annual and daily temperature differences, in regions with high humidity, that is, in such conditions where traditional facade materials have a short service life. Therefore, the mass use of ventilated facades allows to increase the energy-saving and environmental characteristics of buildings and, thus, to improve the environmental characteristics of the urban atmosphere [3].

Thus, hot and arid climate creates uncomfortable living conditions and staying in buildings due to significant overheating of premises, which makes the problem of improving the energy performance of building systems relevant. Experimental study conducted in the construction of a wall was with the ventilated façade of a school under construction. The results of the experiment showed that in the afternoon of July, the "green" facade could provide an average temperature $50 \mathrm{~K}$ lower than the usual wall, improving the energy performance of the building and reducing the load on cooling. In the process of solar irradiation of the structure, part of the thermal energy is absorbed by the outer surface, part - is lost due to heat exchange with the environment, part - is heated [6]. 


\section{EXPERIMENT RESULTS}

The Department of Heat Gas and Water Supply of South-West State University conducts research on the use of new structural materials for creating environmental friendly and energy-saving ventilated building envelopes and developing their structures.

To create this type of ventilated building envelopes it is proposed to use constructions based on granulated blast furnace slag, which has good thermal and structural properties and also proved to be a good adsorbent in the process of cleaning of gaseous combustion products from harmful components (nitrogen oxides, sulfur oxides), which are also the main pollutants of outdoor air $[7,8]$.

Adsorption properties of granulated blast furnace slag were carried out on the example of flue gas treatment of an autonomous heat generator operating on natural gas. Since the main harmful impurities of outdoor air $\left(\mathrm{NO}_{x}\right.$, $\mathrm{SO}_{\mathrm{x}}$ ), as well as impurities in flue gases, have acidic properties, blast furnace slag with the module of basicity $M>1$ (namely, granulated blast furnace slag of Novolipetsk metallurgical plant) was used for constructions of ventilated fences.

The experiment was carried out on a gas water heater equipped with a flue gas cleaning unit, which is a nozzle filled with granulated blast furnace slag (Fig. 1) when it works in real conditions.

\section{To the atmosphere}

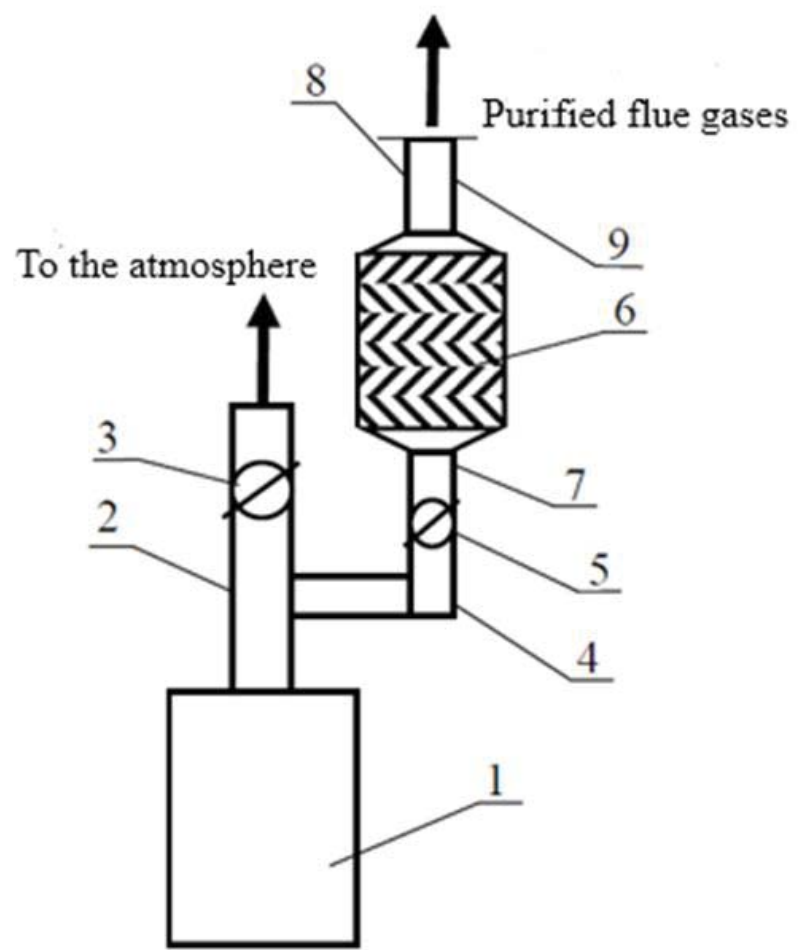

Figure 1: The scheme of the experimental installation: 1-gas water heater; 2- internal chimney; 4- chimney outlet; 3,5-sliders; 6- flue gas cleaning nozzle;

7,8- sampling zone; 9- external chimney.
The results of the experiment carried out at different loads of the heat generator are given in Table 1 . The amount of absorbed $\mathrm{CO}, \mathrm{NO}_{x}, \mathrm{CO}_{2}$ in \% was determined by the formula:

$W=\frac{V_{H}-V_{K}}{V_{H}} \times 100 \%$

Where, $\mathrm{W}$ is the amount of $\mathrm{CO}, \mathrm{NO}_{x}, \mathrm{CO}_{2}$ removed in \%; $\mathrm{V}_{\mathrm{H}}$ - The amount of $\mathrm{CO}, \mathrm{NO}_{x}, \mathrm{CO}_{2}$ before the nozzle; $\mathrm{V}_{\mathrm{K}}$ - The amount of $\mathrm{CO}, \mathrm{NO}_{\mathrm{x}}, \mathrm{CO}_{2}$ after the nozzle.

The results of the experiment to determine the degree of purification of flue gases from $\mathrm{NO}_{x}, \mathrm{CO}, \mathrm{CO}_{2}$ at different temperatures of flue gases at the inlet to the nozzle are given in Table 1.

The results of the experiment show that the proposed adsorbent (granulated blast furnace slags) allows reducing the amount of harmful substances emitted into the atmosphere by burning natural gas (nitrogen oxides $\left(\mathrm{NO}_{x}\right.$ ) by $45-55 \%$, carbon monoxide (CO) by $10-30 \%$, carbon dioxide $\left(\mathrm{CO}_{2}\right)$ by $15-25 \%$.

The time of protective action of the adsorbent (saturation with absorbed components, $\mathrm{NO}_{\mathrm{x}}, \mathrm{CO}_{\mathrm{x}}$ ) in the continuous operation of the water heater used in the experiment was 87.5 hours, which is approximately equal to onemonth interval between the processes of regeneration at the average operation of the water heater for 3 hours a day. The adsorbent was regenerated by flushing with tap water. The amount of water used for regeneration (desorption of absorbed $\mathrm{NO}_{\mathrm{x}}$ and $\mathrm{CO}_{\mathrm{x}}$ from the adsorbent) was determined experimentally. The average water consumption is $2.5 \mathrm{~kg}$ per $1 \mathrm{~kg}$ of blast furnace slag.

Granulated blast furnace slag is a fine-grained material in the form of porous vitreous or crystalline granules with an average size (2-8) and more than $\mathrm{mm}$. Slag density, depending on the composition, is $2.8-3.0 \mathrm{~g} / \mathrm{cm}^{3}$, grain hardness is $5-8 \mathrm{kgs} / \mathrm{cm}^{2}$. The chemical composition of slag, depending on the composition of the initial ore and the type of cast iron, varies widely: $\mathrm{CaO}-30-49 \%$; $\mathrm{AL}_{2} \mathrm{O}_{3}-4.5-20 \% ; \mathrm{SiO}_{2}-33-44 \% ; \mathrm{Fe}_{2} \mathrm{O}_{3}-0.3-0.8 \%$; $\mathrm{MgO}-1.5-15 \%$; $\mathrm{MnO}-0.3-3.0 \%$. Main characteristics of blast furnace slag: porosity, basicity, hydraulic properties, activity [9].

The following characteristics are among the advantages of granulated blast furnace slag in comparison to other adsorbents

1. Basicity. The chemical composition of the studied slag $(\mathrm{CaO}, \mathrm{MgO}, \mathrm{FeO})$ and the chemical composition of harmful impurities of outdoor air (CO, $\mathrm{CO}_{2}, \mathrm{SO}_{\mathrm{x}}, \mathrm{NO}_{\mathrm{x}}$ ) contributes to the active course of chemisorption processes in contrast to activated carbon, zeolites and silica gel, chemisorption processes, in which, during the purification of gases from the above mentioned contaminants, these processes are insignificant; 
Table1: Experiment results

\begin{tabular}{|c|c|c|c|c|c|c|c|c|c|}
\hline $\begin{array}{l}\text { № } \\
\text { n/a }\end{array}$ & Measured values & $\begin{array}{l}\text { Units of } \\
\text { measurement }\end{array}$ & 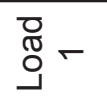 & 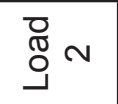 & गु్ $m$ & 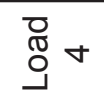 & م & סु & $\stackrel{\mathbb{\pi}}{\pi}_{1} \wedge$ \\
\hline 1 & Flue gas consumption, $\mathrm{G}$ & $\mathrm{m}^{3} / \mathrm{s} \times 10^{3}$ & 2.98 & 3.50 & 4.01 & 4.63 & 5.04 & 5.45 & 6.01 \\
\hline 2 & Initial temperature, gases $T_{1}$ & ${ }^{\circ} \mathrm{C}$ & 110 & 125 & 140 & 155 & 170 & 185 & 200 \\
\hline 3 & Final gas temperature, $T_{2}$ & ${ }^{\circ} \mathrm{C}$ & 66 & 76 & 87 & 98 & 106 & 114 & 119 \\
\hline 4 & $\begin{array}{l}\text { Temperature loss in the } \\
\text { nozzle, } \Delta T\end{array}$ & ${ }^{\circ} \mathrm{C}$ & 44 & 49 & 53 & 57 & 64 & 71 & 81 \\
\hline 5 & Initial concentration $\mathrm{CO}$ & $\mathrm{mg} / \mathrm{m}^{3}$ & 36 & 35 & 35 & 35 & 34 & 34 & 36 \\
\hline 6 & Final conce & $\mathrm{mg} / \mathrm{m}^{3}$ & 31 & 30 & 30 & 29 & 28 & 28 & 28 \\
\hline 7 & Absorbed amount of $\mathrm{CO}$ & $\%$ & 13,9 & 14,3 & 14,3 & 17,1 & 17,6 & 17,6 & 22,2 \\
\hline 8 & Initial concentration of $\mathrm{CO}_{2}$ & vol \% & 5,9 & 5,9 & 5,8 & 5,9 & 5,8 & 5,9 & 5,9 \\
\hline 9 & Final concentration of $\mathrm{CO}_{2}$ & vol \% & 4,6 & 4,6 & 4,5 & 4,5 & 4,4 & 4,4 & 4,4 \\
\hline 10 & Absorbed amount of $\mathrm{CO}_{2}$ & $\%$ & 22,0 & 22,0 & 22,4 & 23,7 & 24,1 & 25,4 & 25,4 \\
\hline 11 & Initial concentration of $\mathrm{NO}_{x}$ & $\mathrm{mg} / \mathrm{m}^{3}$ & 70 & 71 & 71 & 71 & 70 & 70 & 71 \\
\hline 12 & Final concentration of $\mathrm{NO}_{x}$ & $\mathrm{mg} / \mathrm{m}^{3}$ & 32 & 32 & 33 & 33 & 34 & 35 & 37 \\
\hline 13 & Absorbed amount of $\mathrm{NO}_{x}$ & $\%$ & 54,3 & 54,9 & 53,5 & 53,5 & 51,4 & 50,0 & 47,9 \\
\hline 14 & $\begin{array}{l}\text { Aerodynamic resistance of } \\
\text { the nozzle }\end{array}$ & $\mathrm{Pa}$ & 14,57 & 17,12 & 19,61 & 22,64 & 24,65 & 26,65 & 29,39 \\
\hline 15 & Self-propelled & $\mathrm{Pa}$ & 29.44 & 30.86 & 31.27 & 33.19 & 34.74 & 35.57 & 36,84 \\
\hline
\end{tabular}

1. Porosity. Blast furnace slag is a macroporous adsorbent by the characteristics of pores, activated carbon, silica gel, zeolites - microporous;

2. Mechanical strength. Disadvantage of activated carbon is low mechanical strength, cracking and dust formation during operation. According to these characteristics blast furnace slag, zeolites and silica gel has advantages;

3. Heat resistance. Maximum thermal stability is the blast furnace granulated slag, $1600^{\circ} \mathrm{C}$. The minimum value of thermal stability is silica gel, at temperatures above $400{ }^{\circ} \mathrm{C}$ there is a change in its physical structure, leading to a reduction in adsorption capacity - a reduction in the pore surface. Zeolites and activated carbon have an intermediate value of thermal stability, namely $-950^{\circ} \mathrm{C}$ and $1000^{\circ} \mathrm{C}$, respectively;

4. Price. Market value of blast furnace granulated slag in comparison with other above-mentioned adsorbents is hundreds times lower.

The technological advantages of blast furnace slag include:

1. Low formation of reaction by-products during its operation as an adsorbent;
2. Sanitary safety of blast furnace slag due to the technology of obtaining granulated blast furnace slag (cast iron is melted at high temperatures);

3. Simple operation technology and replacement of used adsorbent with fresh one.

Figure 2 shows an example of a ventilated building envelope design based on granulated blast furnace slags - a technical solution for passive outdoor air purification and improvement of energy-saving characteristics of the building - an air-cleaning ventilated building envelope [10].

The work of the building envelope is as follows. In summer and transition periods (due to the high intensity of vehicles in these periods, the concentration of harmful components in the outdoor air is maximal), depending on the direction and strength of the wind, the outdoor air can be supplied (with weak or no wind), mainly in the air gap 7 between the decorative enclosures 1 and the external enclosures 5 through the slots 8 , located in the lower part of the decorative enclosures 1 (for example, at the basement of the building), through the living section of slag granules 4 from the outside, moves along the air gap 7 from the bottom upwards, simultaneously reducing the amount of heat coming from sunlight into the 

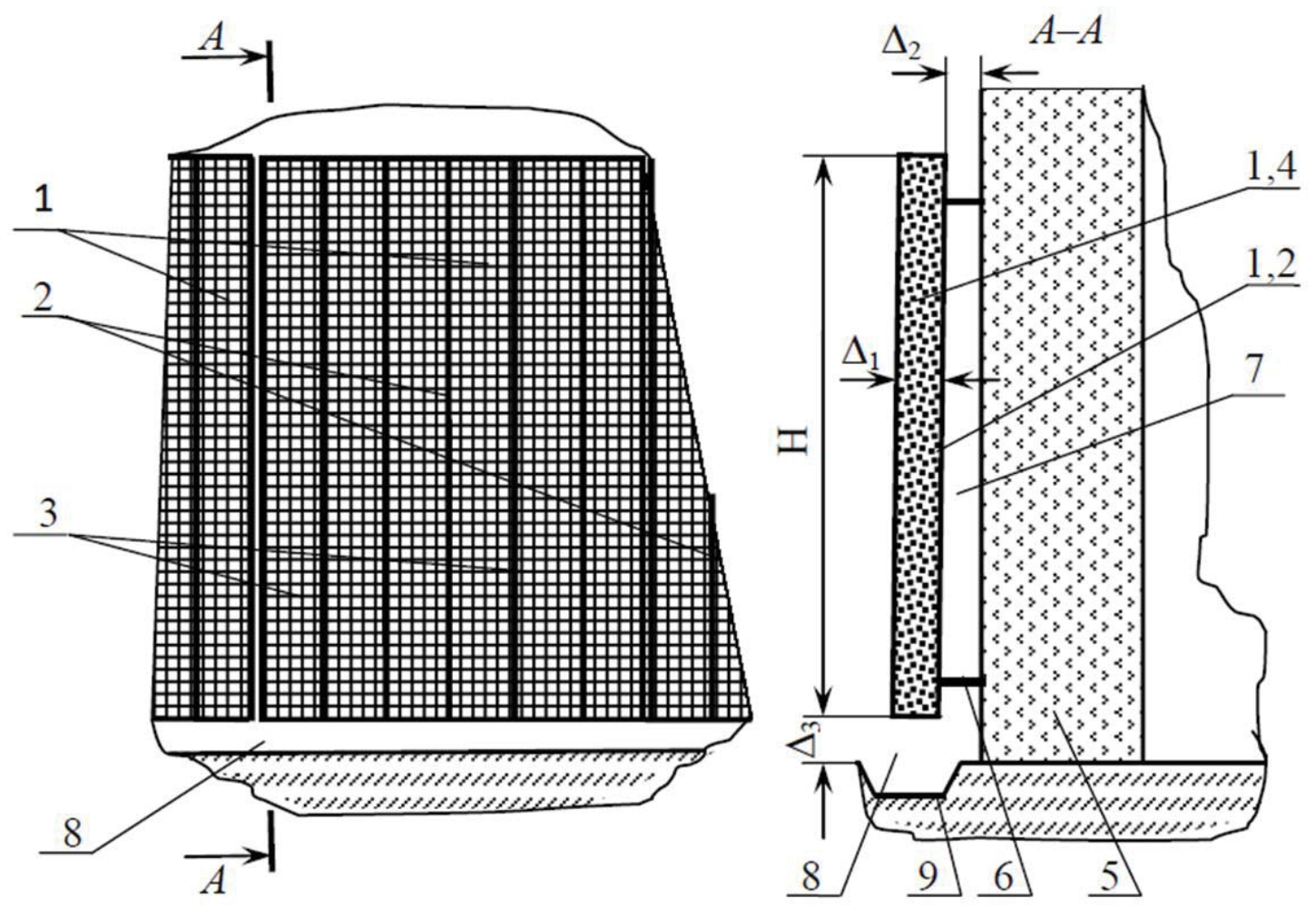

Figure 2: Air-cleaning ventilated enclosures of the building: 1-decorative building enclosure; 2- rectangular frame; 3-mesh rectangular capacity; 4-granules of pumice made of metallurgical slags; 5-outside enclosures; 6-fastening;

7-air gap; 8- slot; 9- storm sewerage.

building,and creating a thrust in the gap 7 and penetrates through the perforation of the inner side of the mesh tank 3 , filled with granules of metallurgical slag pumice 4, where it is cleared of a significant part of harmful components (carbon dioxide, nitrogen oxides, sulfur oxides, soot, ozone, etc.). e.) by their adsorption on the surface and in the pores of the granules 4 [11] and through the external perforation of the container 3 goes to the pedestrian side of the street. At strong wind of the outdoor air, on the contrary, at the expense of wind pressure arrives in granules of slag through external perforation of capacity 3 , gets cleaned from harmful components on granules 4 , leaves through internal perforation of capacity 3 , then on a gap 7 the purified air also arrives in a pathway zone of the street.

At the same time, acidified water discharged into the storm sewerage system 9 , due to the significant content of carbon dioxide in it will contribute to photosynthesis processes [12, p. 210] in the case of its discharge to the irrigation fields of municipal wastewater treatment plants, soil, filtration fields, and evaporation fields.

At the same time, in the period of high temperatures the decorative enclosure due to high porosity of granules of slag pumice 4 (granule pores 4 are filled with air) and air gap 7 creates a significant thermal resistance to the penetration of solar radiation on the surface of the outer enclosure 5 , thus protecting it from excessive heating and increasing the temperature in the premises of the building, which allows you to significantly reduce energy consumption for air conditioning.
At negative temperatures, cold outside air also enters the air gap 7 between the decorative enclosures 1 and the external enclosures 5 through the gap 8, located in the lower part of the decorative enclosures 1 , and moves along the air gap 7 from bottom to top, creates additional thermal resistance, thus reducing the heat loss of the building, while simultaneously heating up the slag granules 4, which sorb the harmful components. Thus, in connection with impossibility of regeneration of granules 4 and possibility of formation of an ice crust on an external surface of enclosure 1 cleaning ability of the enclosure sharply decreases.

\section{CONCLUSIONS}

1. A new structural material for the production of curtain-type ventilated facades (ventilated fences) granulated blast furnace slags - has been proposed;

2. The experiment to check adsorption properties of the proposed structural material - granulated pumice made of basic metallurgical slags with the module of basicity $M>1$ (granulated blast furnace slag) on the example of flue gas purification obtained by burning natural gas, which showed that the proposed structural material is well adsorbed by harmful components contained in the outdoor air $\left(\mathrm{NO}_{\mathrm{x}}, \mathrm{SO}_{\mathrm{x}}\right.$, etc.);

3. The offered material - granulated blast furnace slag - has high structural, thermal-physical and adsorption properties, which allow to significantly increase energy-saving and ecological characteristics of ven- 
tilated building envelopes and, accordingly, facades of buildings and structures;

4. An innovative design of the curtain-type ventilated facade of the building (ventilated fence) on the basis of granulated blast furnace slag has been developed, which allows to simultaneously clean the outdoor air from a significant part of nitrogen oxides, sulphur oxides, carbon monoxides, soot and dust particles, to reduce heat inflow into the building in summer and its heat loss in winter, which significantly increases the environmental and economic efficiency of buildings and structures.

\section{REFERENCES}

1. Aflaki A, Mahyuddin N, Mahmoud ZA-C, Baharum MR. A review on natural ventilation applications through building façade components and ventilation openings in tropical climates. Energy Build 2015; 101: 153-62.

2. Zemella G, Faraguna A. Evolutionary optimizationof façade design. London: Springer; 2014.

3. V.G. Grudachev, I.V. Petrova Ventilated facade systems of civil buildings, textbook, editorial and publishing department CPI Moscow polytechnic university Cheboksary 2010 UDC 693 (075.8) BBK

4. Aksamija A. Sustainable facades: design methods for high-performance building envelopes. New Jersey: John Wiley \& Sons; 2013.

5. Mirrahimi S, Mohamed MF, Haw LC, Ibrahim NLN, Yusoff WFM, Aflaki A. The effect of building envelope on the thermal comfort and energy saving for highrise buildings in hot - humid climate. Renew Sustain Energy Rev 2016; 53: 1508-19.
6. Haggag M., Hassan A., Elmasry S. Experimental study on reduced heat gain through green façades in a high heat load climate. Energy and Buildings. 2014.No.82, P. 668-674

7. Ezhov V, S., Sokolenko N.S. Improving the environmental safety of heat generators of individual heat supply systems in residential areas / V.S. Ezhov // Life Safety, No. 12, 2013, S. 33-34.

8. Ezhov, V.S. Biosphere-compatible heating systems for residential buildings / V.S. Ezhov, N.E. Semicheva, N.S. Sokolenko. - LAP, 2014. -- 126 p.

9. GOST 3476-74 Granulated and electrothermophosphate slag granulated for the production of cements. - M .: IPK Publishing House of Standards, 1976. - 5p.

10. RF patent No. 2633621, MPK F04 C2 / 26, Ventilation air-cleaning building envelope / V.S. Ezhov, N.V. Bredikhina, A.A. Dorodnikh. Publ. 10/16/2017, Byul. No. 29.

11. Nenitsesku K. General chemistry - M .: Mir, 1968, p. 708.

12. Komov V.P. et al. Biochemistry. - M.: Drofa, 2004, p. 620

13. Yezhov, V., Ezhova, T., Semicheva, N., \& Makhova, V. [2017]. Outdoor air conditioning. Journal of Applied Engineering Science, 15(3), 313-318. 